\title{
Antioxidant capacity, C-vitamin and anthocyanin content in the fruits of elderberry (Sambucus nigra L.) types
}

\author{
Szabó N. ${ }^{1}$, Sipos B. Z. ${ }^{1}$ and Stefanovits-Bányai É. ${ }^{2}$ \\ BUESPA, Faculty of Horticultural Science, ${ }^{l}$ Department of Fruit Science \\ ${ }^{2}$ Faculty of Food Science, Department of Applied Chemistry \\ 1118 Budapest, Villányi út 29-43, Hungary
}

\begin{abstract}
Summary: Elderberry used to be a common medicinal plant since long. Its ripe fruit and inflorescence has been collected. Cultivation however, started in Hungary recently, with the early 90 -es. Initially, has been planted, the 'Haschberg' cultivar. Our Department started first with the selection of favourable genotypes in the Hungarian spontaneous populations of the species, we aimed to find clones, which are earlier ripening than 'Haschberg', moreover, superior in any of the agronomical or quality traits. Present study deals with 19 new selected clones by their content of vitamin-C, anthocyanins and their antioxidant capacity. Environmental stresses are inducing, increased, accumulation of free radicals in living organisms. To evoid the harmful effects of the free radicals, we need to consume antioxidant compounds (flavonoids, anthocyanins, vitamins, etc.) In the literature there are quite a few references related to the anthocyanins and antioxidants of the elderberry. Measurements prove that substantial differences exist among the population of the species as for the content and quality of those compounds. In anthocyanin content, the difference between the highest and lowest values was $3000 \mathrm{mg} / \mathrm{l}$, whereas in antioxidant content this value was $600 \mu \mathrm{M}$. Those types, which contained less anthocyanin $(<5000 \mathrm{mg} / \mathrm{l})$, produced lower antioxidant capacity, whereas the highest anthocyanin content was associated with the strongest antioxidant activity. C-vitamin content varied between 36.5 and $96.4 \mathrm{mg} / 100 \mathrm{~g}$. These values provide daily human requirements by their consumption. Summing up all parameters, examined the best type was Cinkota 1 .
\end{abstract}

Key words: black elder, Sambucus nigra L:, anthocyanin, vitamin C, antioxidant capacity

\section{Introduction}

The requirement of developing healthy diets turned the attention to the ripe berries of elderberry, as a favourable source of valuable chemical compounds, moreover, one of the most applied organic dyes of food industry (StollGremminger,1986). Elderberry, as a medicinal plant has been collected since the earliest times for its fruit as well as for its flower (Keipert, 1981; Sipos,1998; RápótyRomváry,1990). To the tea cooked from the flowers antiphlogistic, sweeting and diuretic effects are attributed, whereas the ripe fruit could be used for tea or for marmalade, both with curative abilities. Leaves, bark and root are also used as drogs. The colouring substance of the berry is composed of cyanidin-type anthocyanins, cyanin, chrysanthemin and quercetin. The anthocyanins contain cyanidin-3-glycosid and cyanidin-3-sambubiosid (KaackKidmose, 1993; Albrecht, 1993).

The cultivation of elder started about the end of 1990-es in Hungary, and atteined according to statistical data, in 2000, already 1600 hectares, in 2003, about 3000 ha plantations have been registerd. Practically, the only cultivar, the Austrian 'Haschberg' has been planted. Undoubtedly, it is considered as the best cultivar, agronomically as well as in processing, but the sychronous ripening time may cause serious concern in large plantations and in processing plants. At the Department of Fruit Science, we aimed to find genotypes of earlier ripening with equal or even better quality for the industry (Sipos-Szabó,2003; Sipos,2002; Stéger et al, 1999).

Components of the fruit, as vitamins, carotenoids, flavonoids, anthocyanins, etc., are valuable, nay, indispensable for the organism, thus highly desirable in a healthy diet being complementary constituents of therapies (Stefanovits-Schiffler et al, 2004). Most of the antioxidants of small molecules are to be incorporated in the normal foods of the daily diet, and their physiological role is the maintenance of normal metabolic processes by neutralising the noxious oxidative radicals. That means, several diseases could be avoided without special drugs designed for that special purpose. Antioxidants naturally occurring in common foods gained high popularity and are generally preferred (Herbert, 1996; Himelrick, 2002).

Our studies dealing with elderberry have been extended to the natural antioxidants with the hope to utilise elder as a source of the respective compounds. For that purpose, not only antioxidants but also functionally related antocianins and vitamin- $\mathrm{C}$ have been measured.

\section{Material and method}

Measurements have been performed on fruit samples of 19 wild growing genotypes of elderberry (Sambucus nigra 
L.). The samples were collected at the experimental farm of the Faculty, Szigetcsép (Szcs-2, Szcs-3, Szcs-5, Szcs-K1, Lizi korai), at Fajsz (Fajsz-3, Fajsz-4, Fajsz-5, Fajsz-6), one type at Gyenesdiás (Gy-1), moreover, around the lake Naplás (Cinkota-1, Meszes, Karám-1, Karám-2, Naplás-4, Naplás-9, Naplás-10, Naplás-16) in August 2003. The original Austrian 'Haschberg' served as a control and was grown at the experimental farm.

Analyses were performed on the pressed juice of the berries. The overall antioxidant activity has been determined according to Benzie \& Strain (1996) (FRAP=Ferric Reducing Ability of Plasma). Essentially, FRAP means that the ferri- $\left(\mathrm{Fe}^{3+}\right)$-ions are reduced to ferro- $\left(\mathrm{Fe}^{2+}\right)$-ions by the activity of antioxidants. Those ions are bound to tripyridiltiazin (TPTZ) at low $\mathrm{pH}$ values, and the respective complex, $\mathrm{Fe}^{2+}$-TPTZ, gives an intense blue colour, which is measured by photometry. The FRAP value is obtained by compairing the extinction-values with that of $\mathrm{Fe}^{2+}$ solutions of known concentrations at $593 \mathrm{~nm}$ wavelength.

Anthocyanin content is determined by spectrophotometry according to Füleki \& Francis (1968). The absorbance has been checked at $540 \mathrm{~nm}$ after a darkness for 30 minutes. The calculation was made according to the formula:

$$
\begin{gathered}
\mathrm{C}(\mathrm{mg} / \mathrm{l})=15 \times \mathrm{A}_{\max } \times \text { dilution } \\
\mathrm{A}_{\max }=\text { the value of maximal absorbancy }
\end{gathered}
$$

Vitamin-C content was measured according to the Hungarian standard MSZ ISO 6557-2. Extraction of the sample was made by a solution of oxalic acid. The coloured reagent, 2,6-dichloro-phenol-indophenol was reduced by ascorbinic acid, quantitatively, the remnants of the reagent was extracted by xylol and the absorbance was determined by spectrophotometry at $500 \mathrm{~nm}$ wavelength.

\section{Results}

Anthocyanin content of the samples varied between 4845 $\mathrm{mg} / \mathrm{l}$ and $7913 \mathrm{mg} / \mathrm{l}$. The highest values are found in Cinkota1 , which excelled also in other characters and fruit quality from. Ripening time was earlier than that of 'Haschberg' by a few days, berries are large and it is a good yielder. Surprisingly high anthocyanin content was stated in Lizi korai (6975 mg/l), being 2 weeks earlier than 'Haschberg' and produced high yield. Outstanding values are found in Szcs-5, which has been favourably registered for several years because of its yields and berry size. Its single disadvantage is the vigorous growth. 'Haschberg' was the second best in anthocyanin content, with $7815 \mathrm{mg} / \mathrm{l}$.

The high antioxidant-capacity at elder clones is evident according to our data. Differences, however, are much smaller than obtained in anthocyanin content. Best types were Szcs-K1, Naplás 10 and Cinkota-1. 'Haschberg' did not produce high values, but the majority of accessions prove some association between anthocyanin-content and antioxidant activity (Figure 1,2).

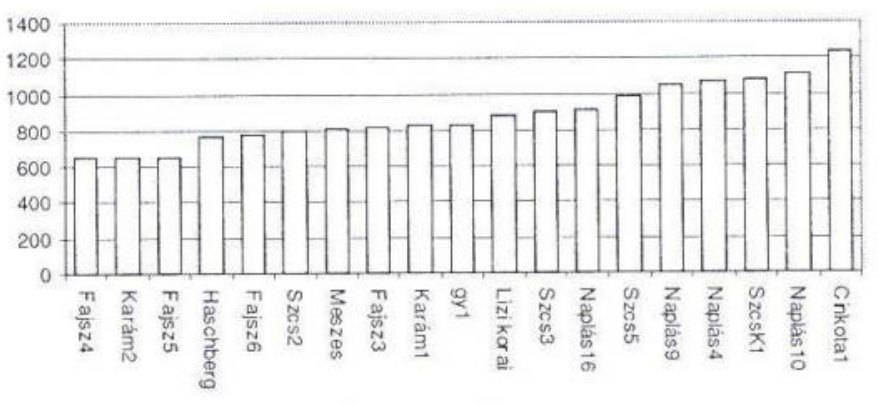

Figure 1 Antioxidant capacity of black elder types ( $\mu \mathrm{M}$ AA)

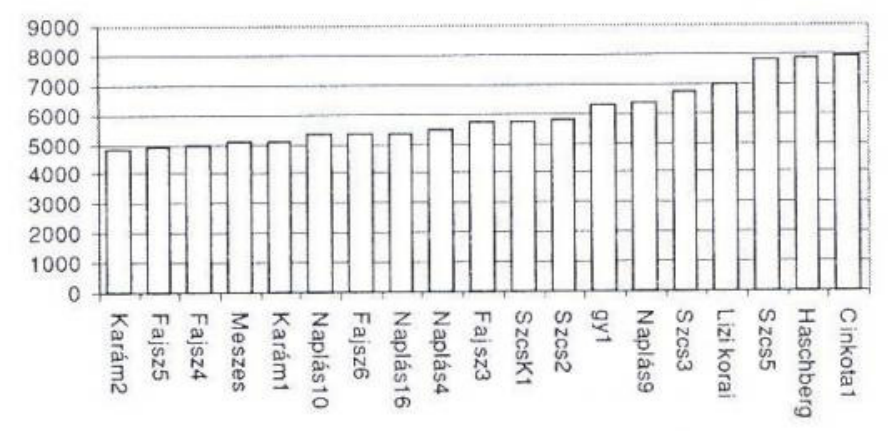

Figure 2 Anthocyanin content of black elder types (mg/l)

In elderberries, vitamin- $C$ is also active as an antioxidant. Earlier tests suggested that most genotypes contained similar concentration of vitamin-C as 'Haschberg'. Values of vitamin-C content varied between 36.5 and $96.4 \mathrm{mg} / 100 \mathrm{~g}$. Highest values were obtained in Cinkota-1, like in the former two parameters. Near to this, good values were found in Szcs-5 and in 'Haschberg' (Figure 3) too. Favourable values are also presented in Szcs-3, which is a type of intermediate vigour but with excellent yields.

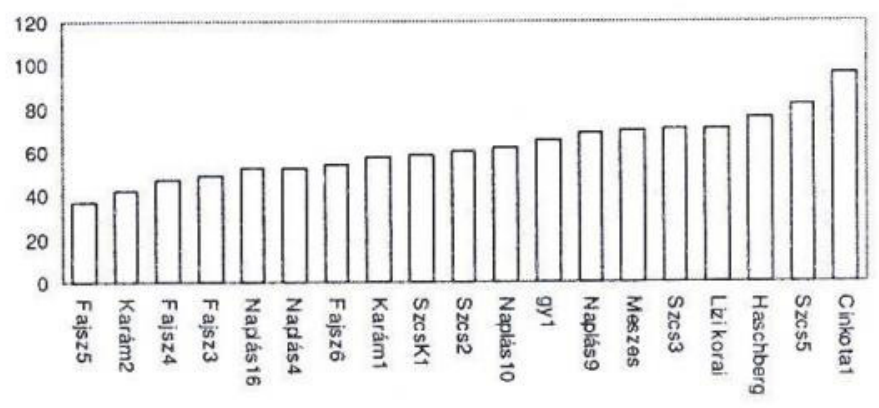

Figure 3 C-vitamin content of black elder types $(\mathrm{mg} / 100 \mathrm{~g})$

\section{Conclusions}

Summing up the results, it is evident that the three parameters are rather balanced and related with each other. Best types were Cinkota-1, Szcs-5 and 'Haschberg'. In the majority of samples high contents of anthocyanin, vitamin-C and andioxidant capacity are associated, except 'Haschberg', which had mediocre antioxidant activity in spite of high values in vitamin- $\mathrm{C}$ and anthocyanin. 


\section{References}

Albrecht, H-J. et. al. (1993): Anbau und Verwertung von Wildobst. Bernhard Thalacker Verlag, Braunschweig, 22-26.

Benzie, F. \& Strain, J. J. (1996): The ferric reducing ability of plasma (FRAP) as a measuring of "antioxidant power": The FRAP assay. Annual Biochem 239: 70-76.

Füleki, T. \& Francis, F. J. (1968): Quantitative methods for anthocyanins 2. Journal Food Science, 33: 78.

Gencsi, L. \& Vancsura, R. (1992): Dendrológia, Mezógazda Kiadó, Budapest

Herbert, V. (1996): Introduction.Symposium: Prooxidant effects of antioxidant vitamins. Journal of Nutrition. 126: 1197-1200.

Himelrick, D. (2002): Analyzing health benefits in berries. American Fruit Grower. (3): 22

Kaack, K. \& Kidmose, U. (1993): Erfahrungen in Anbau von Holunder in Danemark. Anbau und Verwertung von Wildobst. Bernhard Thalacker Verlag , Braunschweig

Keipert, K. (1981): Gattung Sambucus-Holunder. Beerenobst, Eug. Ulmer Veri., 234-235

KSH (2002): Gyümölcsültetvények Magyarországon, 2001. 10-13 Papp, J. \& Porpáczy, A. (1999): Bogyósgyümölcsúek II., Mezógazda Kiadó, Budapest, 193-198.
Rápóti, J. \& Romváry, V. (1990): Gyógyító növények. Medicina. Budapest 89-91.

Sipos, B. Z. (1998): A feketebodza értékei. Kertgazdaság 1998. (30) (2): 64-66.

Sipos, B. Z. (2002): Bodzatermesztés. Alakító és termốkori metszés. Kertészet és Szôlészet 51: (5): 8-11

Sipos, B. Z. \& Szabó, N. (2003): Fekete bodza (Sambucus nigra L.) genotípusok virágzatának és gyümölcsének jellemzôi. LippayOrmos-Vas Tudományos Ülésszak, Budapest, 356.

Stefanovits-Bányai, É., Schiffler, E., Stéger-Máté, M., Sipos, B. Z. \& Hegedüs A. (2004): A fekete bodza (Sambucus nigra L.) beltartaimi értékeinek és antioxidáns hatásának változása az érés folyamán. Olaj, szappan, kozmetika 53 (1): 33-35.

Stéger-Máté, M., Horváth, D-né \& Sipos, B. Z. (1999): Hazai körkép a fekete bodza termesztésérốl és feldolgozásáról. Konzervújság 1999 (2): 47-49.

Stoll, K. \& Gremminger, U. (1986): Besondere Obstarten. Eugen Ulmer Verlag, 66-75.

Szabó N. (2002): Szelektált feketebodza típusok (Sambucus nigra L.) értékelése termesztési és élelmiszeripari szempontok szerint. (Diplomamunka, Szent István Egyetem Gyümölcstermố Növények Tanszék, Budapest) 